International Journal of Applied Linguistics \& English Literature

ISSN 2200-3592 (Print), ISSN 2200-3452 (Online)

Vol. 1 No. 6; November 2012

\title{
On the Effect of Task-Complexity-Based Instruction of Incidental Vocabulary on Iranian Academic Learners' Vocabulary Learning
}

\author{
Parviz Alavinia (Corresponding author) \\ $\mathrm{PhD}$, Assistant Professor \\ Faculty of Humanities and Letters, Urmia University \\ Valfajr 2 Blvd., Urmia, West Azerbaijan, Iran
}

Tel: 00980441 3362008-12, E-mail: pevinia2006@yahoo.com

Alireza Bonyadi

$\mathrm{PhD}$, Assistant Professor

Department of English Language and Literature

Urmia Branch, Islamic Azad University, Urmia, Iran

Tel: 00980441 2719900,E-mail: bonyadi.alireza@yahoo.com

Fariborz Malehmir Chegini, MA,

English Department, Sciences and Research Branch

Islamic Azad University, West Azerbaijan, Iran.

Tel: 00980441 2719900,E-mail: fariborzm.chegini@yahoo.com

Received: 25-06- 2012

doi:10.7575/ijalel.v.1n.6p.26
Accepted: 29-07- 2012

Published: 01-11- 2012

URL: http://dx.doi.org/10.7575/ijalel.v.1n.6p.26

\begin{abstract}
Though extensive work has been appropriated to probing different perspectives of task-based instruction and its usefulness in pedagogy, it still seems that meager heed has been given to the implications of task complexity for the acquisition and retention of vocabulary, among other language components. In an attempt to bridge this ostensible gap, the researchers in the present study strived to find the would-be effects of task-complexity-based incidental vocabulary instruction on learners' vocabulary learning. The study was conducted with sixty Iranian academic learners, and the instruments used were Nelson Test and English Vocabulary in Use Elementary Level Test. Based on the findings gained through running t-test analysis, experimental group participants were found to have made a significant improvement apropos vocabulary performance as a result of treatment via task-complexity-based instruction.
\end{abstract}

Keywords: Incidental vocabulary, Iranian academic non-EFL learners, task complexity, task-complexity-based instruction

\section{Introduction}

\subsection{Background}

Since its inception through the pioneering work of Prabhu, task based instruction has always been in the foreground of attention of manifold researchers, practitioners and all those involved with varied aspects of pedagogical endeavors. As Ruso $(2007$, p. 2) puts it, "Prabhu stands as the first significant person in the development of TBL. His main contribution has been raising awareness of the ELT world to TBL." In his early attempts to popularize the notion of task, he delineated the term as "an activity which required learners to arrive at an outcome from given information through some process of thought, and which allowed teachers to control and regulate that process" (Prabhu, 1987, p. 24). 
"Task-based learning was first developed by N. Prabhu in Bangladore, southern India. Prabhu believed that students may learn more effectively when their minds are focused on the task, rather than on the language they are using." (Prabhu, 1987, cited in Büyükkarci, 2009, p. 314). Büyükkarci (2009, pp. 314-15), then, refers to Breen's (1987) description of task (cited in Richards \& Rodgers, 2001, p. 233) where he notes,

A language learning task can be regarded as a springboard for learning work. In a broad sense, it is a structured plan for the provision of opportunities for the refinement of knowledge and capabilities entailed in a new language and its use during communication. Such a work plan will have its own particular objective, appropriate content which is to be worked upon, and a working procedure... A simple and brief exercise is a task, and also are more complex and comprehensive work plans which require spontaneous communication of meaning or the solving of the problems in learning and communicating. Any language test can be included within this spectrum of tasks. All materials designed for language teaching-through their particular organization of content and the working procedures they assume or propose for the learning of content- can be seen as compendia of tasks.

As Sánchez (2004, p.39) contends, "Task-Based Approach (TBA) has gained popularity in the field of language teaching since the last decade of the 20th Century and significant scholars have joined the discussion and increased the amount of analytical studies on the issue."

A rather comprehensive definition of task is the one put forth by Long (1985), where he defines it as,

A piece of work undertaken for oneself or for others, freely or for some reward. Thus, examples of tasks include painting a fence, dressing a child, filling out a form, buying a pair of shoes, making an airline reservation, borrowing a library book, taking a driving test, typing a letter, weighing a patient, sorting letters, taking a hotel reservation, writing a check, finding a street destination and helping someone across a road. In other words, by 'task' is meant the hundred and one things people do in everyday life, at work, at play, and in between. Tasks are the things people will tell you they do if you ask them and they are not applied linguists (p. 89).

In line with Long and Crookes (1992, p. 27), "three new, task-based syllabus types appeared in the 1980s: (a) the procedural syllabus, (b) the process syllabus, and (c) the task-syllabus", all of which "reject linguistic elements as the unit of analysis and opt instead for some conception of task". Crookes (1986, p. 1) defines task as "a piece of work or an activity, usually with a specified objective, undertaken as part of an educational course, or at work".

It is also worth noting, at this juncture, that Crookes' definition mentioned above takes a more classroom-oriented approach, and is, hence, in sharp contrast to Long's delineation of the concept (also stated above) in which he puts more emphasis on the real world tasks. Thus, Crook's definition might be said to draw more on the course requirements, whereas Long's is rather concerned with the identification of learners' needs (Sánchez, 2004). After this brief introduction to the concept of task, it might prove helpful to set out for a more focused journey through some of the key issues in the implementation of task, such as task complexity and difficulty.

Task complexity, as Lijuan (2010, p. 48) discusses, (quoting Robinson, 2001) is defined as "the result of the attentional focus, working memory, reasoning and other cognitive demands imposed by the structure of the task on the language learner."

Further elaboration on the notion of task is provided in Ellis (2003) where he asserts,

The ease with which learners are able to perform different tasks depends on three sets of factors. First, there are the inherent characteristics of the task itself. These relate to the nature of the input, the task conditions, the processing operations involved in completing the task and the outcome that is required. Robinson (2001: 29) refers to these factors under the heading of task complexity (pp. 220-21).

In the rest of the discussion, Ellis (2003) puts forth five overriding factors which underlie the level of task complexity. These factors are referred to as input medium, code complexity, cognitive complexity, context dependency and familiarity of information. In terms of input medium, for example, he points out that pictorial or written input is likely to be processed easier and faster than oral one. By code complexity the author means the lexico-grammatical complexity of the task which naturally renders the task more complex and hence more difficult to deal with. Cognitive complexity, in his words, refers to the "cognitive demands of processing the informational content" (Ellis, 2003, p. 222) which, as he underscores, is not any less important than code complexity. The next significant factor contributing to task complexity, context dependency, is also very 
significant in determining the degree of complexity of the task. In line with the author, "Textual input that is supported by visual information in some form is generally easier to process than information with no such support" (Ellis, 2003., p. 223). Finally, familiarity of information has to do with the relevance of the task theme to the learners' general background knowledge; thus, it follows that the less familiar the content of the task, the greater the level of task complexity.

In view of the fact that a major part of the current study focuses on incidental vocabulary learning, which constitutes the dependent variable of the present research, an introduction is needed to be given to what is meant by this category of vocabulary knowledge. As Eysenck (1982) holds, the principal factor that helps differentiate between intentional and incidental learning is the presence of instructions or lack of them thereby, which function as a reminder for learners with regard to the existence of a subsequent retention test (cited in Mahdavy, 2011).

Citing Nation (2001, p. 232), Wu refers to incidental vocabulary learning as "an important strategy in vocabulary learning." In the rest of this quotation we read, incidental vocabulary learning "occurs without specific intention to focus on vocabulary. One can develop vocabulary knowledge subconsciously while being engaged in any language activities, especially reading" (2009, p. 10).

In a similar vein, Hulstijn (2001, p. 271) defines the term incidental vocabulary as "learning of vocabulary as the by-product of any activity not explicitly geared to vocabulary learning," which is, therefore, in sharp contrast to intentional vocabulary learning, which is defined as "any activity geared at committing lexical information to memory."

Though a plethora of work has, thus far, been appropriated to probing varied aspects of task-based instruction, the majority of work done in this domain has mainly centered around two dominant facets of the issue, i.e. rehearsal and strategic planning, as Ellis (2009) puts it. Thus, informed by the paucity of research in the area of task complexity and its implications for vocabulary learning, the current study strives to find the possible effect of task-complexity-based instruction of incidental vocabulary on Iranian learners' vocabulary learning.

\subsection{Significance of the Study}

Among the issues toward which a scant amount of heed has been given in the literature on task lie the possible repercussions of controlling task complexity on learners' academic performance, in general, and their improvement in terms of vocabulary learning, in particular. Being informed of this ostensible gap in the literature, the researchers in the current study are after depicting the effect of task-complexity-based instruction of incidental vocabulary on the learners' (incidental) vocabulary learning.

It might be stated that although part of the significance of the current study, as already stated, lies in the paucity of investigations in this particular area of research, the other factor underlying the need for conducting such a study is the possible effect(s) such a variation in terms of task complexity might have on learners' (incidental) vocabulary learning. To the researchers' best knowledge (as the search through the existing literature helped reveal), no studies, to date, have investigated the go-togetherness between these two novel domains, and hence, the current research might be said to be quite unique in the orientation it takes.

\subsection{Research Question and Hypothesis}

Amid the hunt for a cogent account of the problem raised in the current probe, the following research question was formulated:

RQ: Does task-complexity-based instruction of incidental vocabulary bring about elementary Iranian academic learners' enhanced performance in terms of vocabulary learning?

HO: Task-complexity-based instruction of incidental vocabulary does not bring about elementary Iranian academic learners' enhanced performance in terms of vocabulary learning.

\section{Literature Review}

\subsection{Empirical Research on Task-Based Learning}

In this section an attempt is made to give a brief account of the previous body of research on different aspects of task-based teaching and learning. To provide a reader-friendly review of the existing studies, they have been put in the chronological order. In most of what follows the researchers draw on the seminal work done by Ellis (2009), where he gives a comprehensive classificatory explication of the literature on task, in general and CAF (Complexity, Accuracy and Fluency), in particular. 
An early study on the effect of rehearsal on task complexity, fluency and accuracy (a case study) was conducted by Bygate (1996), where he investigated the effects of repetitive narrative task on a learner's use of language. Based on the findings, he maintained that a slight amount of improvement was observed with regard to the learner's accuracy. The other pieces of upshot gained in this study were the reported changes in that individual's use of complexity and grammatical and lexical variety. There was also an increase in the number of self-correcting repetitions as well as a decrease in the number of inappropriate expressions.

In an attempt to find the effect of rehearsal with the same task or the same task type on the learners' performance on a new task, Bygate (2001) embarked on a study with forty eight ESL learners in UK. As the findings of the study revealed, task repetition had culminated in raised levels of complexity in both narrative and interview tasks, whereas the fluency had been marked by a decrease in the interview, but not in the narrative task. Furthermore, though an enhancement in terms of accuracy had been reported, it was not found to be statistically significant. With regard to task-type rehearsal, however, no significant result was reported.

Yuan and Ellis' (2003) study can be referred to as an instance of seminal works in the area of strategic planning and its effects on learners' fluency, accuracy and complexity. The participants of their study were some forty-two Chinese undergraduate learners majoring in English. Being more interested in spotting the influences of pre-task planning on learners' oral task performance in the three afore-said domains, these two researchers came up with the conclusion that pre-task planning can prove fruitful in enhancing the learners' fluency and complexity, but no significant upshots where gained with respect to the learners' accuracy.

Sangarun's (2005) investigation can feature as another influential piece of work in the field of strategic planning and its effects on learners' oral performance. In this study, the researchers made use of 40 Thai intermediate EFL learners, and implemented three types of planning tasks, i.e. meaning focused, form focused and form and meaning focused. Overall, planning (irrespective of its separate types) was found to be quite effectual in bringing about learners' improved fluency, accuracy and complexity; learners were also reported to have a higher inclination toward focusing on meaning rather than form.

In another study in the domain of task-oriented investigations, Rahimpour (2007) strived to find the extent to which different task types could elicit variable performance in Iranian learners. Based on the findings of the study, the researcher concluded that the performance of learners was characterized by a high degree of variability due to the implementation of different task types.

Finally, in a more recent scrutiny Guará-Tavares (2008) launched a project with fifty intermediate Brazilian learners of English, where the researcher was interested in pinpointing the influence of planning on the triplet factors known as fluency, accuracy and complexity. The other preoccupation of the researcher in this study was determining the possible effect of working memory for learners' task performance. Though a statistically significant upshot was gained with regard to the performance of the experimental group in terms of accuracy and complexity on task two, no such difference was reported as of task one. Furthermore, working memory was found to correlate significantly with accuracy in task two within the control group, whereas for the experimental group, significant correlation was reported with regard to the measures of fluency and complexity.

\subsection{Empirical Research on Incidental Vocabulary}

Incidental vocabulary has been investigated with regard to a multitude of factors, including new word density (Holley, 1973), glossing and/or inferencing (Cobb, 1997; Cobb \& Horst, 2001; Hulstijn, 1992), new word frequency (Rott, 1999), and reading purpose (Swanborn \& Glopper, 2002).

Other perspectives toward which a growing amount of attention has been paid on the part of several researchers are the resources and procedures applied in meaning inference (Haastrup 1991; Parreren \& Shouten-van Parreren, 1981), the influence of reading task and learner factors (Hulstijn, 1993; Grace, 1999), and the effect of dictionary or glossing support (Hulstijn et al., 1996; Knight, 1994; Krantz, 1990; Roby, 1999). In what follows an attempt is made to expose the readers to a number of research projects conducted in the area of incidental vocabulary.

Jing and Jianbin (2009), for instance, were after finding the effect of involvement load hypothesis on incidental vocabulary acquisition in EFL listening. The participants of their study were some 87 second-grade non-English students in three separate parallel classes (with an equal share of learners, i.e. twenty nine participants, in each class). Based on the gained results they held,

the task with higher involvement load, in this experiment, namely, task requiring writing secured the best retention effects, task of multiple choices with marginal glosses relevant to the task produced better 
International Journal of Applied Linguistics \& English Literature

ISSN 2200-3592 (Print), ISSN 2200-3452 (Online)

Vol. 1 No. 6; November 2012

retention result than task of multiple choices with marginal glosses irrelevant to the task, which produced the lowest retention (Jing \& Jianbin, 2009, p. 8).

Also, in a study similar to what the researchers in the current study have done, Behbahani, Pourdana, Maleki, and Javanbakht (2011) intended to find the effect of task-induced involvement on the process of incidental vocabulary learning. Their investigation benefited from Sixty-eight junior high school students. Using three different pieces of tasks, a reading comprehension task followed by five multiple-choice items, a reading comprehension task followed by five fill-in-the-blank items, and a sentence-writing task, the researchers in this study came up with the result that the learners' better performance on the third task (compared to the first and second task), which is to be taken as the higher degree of involvement on this task, led to their higher scores on both the immediate and delayed posttests. Thus, they concluded that more task-induced involvement on the part of learners had resulted in better performance in terms of incidental vocabulary learning.

Furthermore, in a hunt for the distinctions holding between intentional and incidental vocabulary learning, Ahmad (2011) administered two sets of tests, i.e. Standard Confirmation Test and a Contrastive Extempore Test of intentional and incidental vocabulary, to twenty Saudi Arabian students. At the end, the researcher concluded that the learners' performance on incidental vocabulary test had proven to be much better compared to intentional vocabulary test.

Finally, in a quite recent article, Ghabanchi and Ayoubi (2012) investigated the impact of four different reading conditions on the process of incidental vocabulary learning and recall. The participants of this study were 120 intermediate EFL learners, and as the treatment they were asked to read two short texts under four disparate reading conditions (L1 Marginal Glosses, L2 Marginal Glosses, Dictionary Use, and Summary Writing). As the results of their study revealed, "Support was found for the hypothesis that the four vocabulary learning conditions and the time interval between the two tests have a meaningful influence on the retention of the meaning of unfamiliar target words." Further, it was found that, "All of the four reading conditions had a significant effect on incidental learning and recall of the words, but neither the immediate nor the delayed tests revealed significant differences among the four types" (ibid., p. 85).

\section{Method}

\subsection{Participants}

The participants of the current study were originally 80 male and female learners majoring in computer software in Raja Non-profit Institute in Qazvin, Iran. The subjects were chosen among the freshmen with age range of 19 to 21. They were all passing the general English course with one of the researchers in the said institute. Successive to the administration of the proficiency test (Nelson Test for elementary level, test $100 \mathrm{D}$ ) aimed at homogenizing the subjects, twenty subjects were excluded from the original sample on account of their outlying scores, and hence the main study was carried out with the remaining sixty participants. Afterwards, the participants were randomly assigned to two separate groups (an experimental and a control group), each consisting of 30 learners.

Out of the entire 30 participants taking part in group A (the experimental group), $66.7 \%$ were females and $33.3 \%$ were males. Nonetheless, compared to the experimental group, a higher proportion of males $(56.7 \%)$ attended the control group (group B). Thus, the percentage of females present in this latter group amounted to only $43.3 \%$ of the whole.

\subsection{Instrumentation}

A number of varied instruments, including different tests and materials were utilized in the present study. To be more specific, at the very beginning Nelson test (elementary test, number $100 \mathrm{D}$ ) was administered to the participants with the purpose of coming up with a homogeneous sample. Nelson test which is, in effect, a test battery encompassing three separate sections or test books, was originally written by Fowler and Coe and published in 1976 as a collection of three tests each appropriate for a particular level of proficiency, i.e. elementary, intermediate and advanced. The test used for the purpose of performing the current study was randomly selected from the introductory part of the said test, which was designed for elementary level.

Next to holding the homogeneity test, English Vocabulary in Use Elementary Level Test (published by Cambridge University Press, 2010) was administered to the learners as the pretest (and later as the posttest) of the study. It is worth noting that the above-mentioned test was composed of 50 multiple-choice vocabulary questions, and the content of the test was based on the materials covered in the corresponding student book, 
International Journal of Applied Linguistics \& English Literature

ISSN 2200-3592 (Print), ISSN 2200-3452 (Online)

Vol. 1 No. 6; November 2012

which was entitled English Vocabulary in Use for elementary level, written by Michael McCarthy and Felicity O'Dell (2010).

\subsection{Material}

The only material employed in the study was the book entitled Basic Tactics for Listening, out of which complexity-based graded and non-graded tasks were selected and applied to learners as the treatment content. The book was comprised of 24 units, with each unit being presented on four pages. From each unit the four tasks which were presented on the second and third pages were utilized for providing the treatment. It is worth mentioning that the tasks employed were of varied natures (some drawing on the learners' productive skills and others tapping their recognition and perception), and sufficient amount of time in each session was appropriated to the completion of tasks.

\subsection{Design and Procedure}

Since the current study makes use of two separate groups of learners, and exerts treatment for the experimental group, it features as a quasi-experimental piece of research. To commence the study, 80 male and female learners majoring in computer software in Raja Non-profit Institute in Qazvin were selected. It's worth noting that these students were passing their general English course with one of the researchers, and were at the elementary level in terms of language proficiency.

Successive to Nelson test administration, twenty students who were found to be outliers were set aside, and, therefore, the main study was pursued with the remaining 60 subjects, who were later assigned to experimental and control groups (with 30 participants in each group) on a random basis. Afterwards, on the second session of their course, a ready-made test of vocabulary entitled English Vocabulary in Use Elementary Level Test (published by Cambridge University Press, 2010) was given to learners in both groups - as the pretest of the study - to tap their knowledge of vocabulary at the outset of the research.

Subsequent to this stage, the learners in the experimental group were exposed to treatment for a matter of three months (12 educational sessions). The treatment applied in the experimental group was founded on the lessons from Basic Tactics for Listening, whose tasks were graded based on the complexity level, and applied to learners based on the rising level of complexity of the tasks chosen (tasks assigned to this group were ordered from simple to complex by the researchers prior to their implementation). Though the same material was covered in the control group, the level of complexity of the tasks was not kept within control, and hence the participants in this latter group received an amalgam of different lessons and tasks from the said source without any arrangement in terms of complexity level. It's also worth noting that the tasks selected for treatment were in compliance with the topics in Elementary English Vocabulary in Use (McCarthy \& O'Dell, 2010), and were hence thought to provide a rich context for learners to experience the incidental contact with the targeted vocabulary, i.e. the vocabulary forming the main basis of the test given to them as pretest and posttest.

As the learners were passing a three-credit general English course with one of the researchers, one third of each weekly session (which lasted for a 3-hour class time with a break time in between) was allotted to the application of treatment in each group. As the treatment was thought of as a part of their general English course requirement, it was applied during the first hour of each session, after which the learners went through the regular weekly schedule for the course. Further, the content of each session's treatment was composed of four tasks which were administered to learners on two pages and the learners were given sufficient time for the completion of the tasks; the tasks were played for the learners using a laptop connected to speakers, and then ample time was provided for the learners to fulfill the activities required in each segment. Indeed, a variety of task formats were utilized (some drawing on the learners' productive skills and others tapping their recognition and perception), and since the participants were non-English learners, sufficient heed was given to the provision of a good amount of directions and guidelines regarding how the tasks were to be completed.

At the end of the twelve sessions of treatment, the very vocabulary test (English Vocabulary in Use Elementary Level Test) was given to learners once more, this time as the posttest of the study. Ultimately, the results of pretest and posttest were compared to come up with a lucid view with regard to the possible improvements in learners' performance resulting from the treatment applied.

\subsection{Data Analysis}

To analyze the obtained data, the following statistical analyses were employed in the present study: 


\section{International Journal of Applied Linguistics \& English Literature \\ ISSN 2200-3592 (Print), ISSN 2200-3452 (Online)}

Vol. 1 No. 6; November 2012

1) To homogenize the learners on the basis of the initial proficiency test, and to check the normality of the study variables, Kolmogorov-Smirnov test was used.

2) To estimate the possible significant difference between the performances of the two groups of participants on pretest and posttest, (independent samples and paired) t-tests were run.

\section{Results}

\subsection{The Performance of Experimental Group on Pretest and Posttest}

Table 1 reveals the descriptive statistics gained for the performance of the experimental group on pretest and posttest. A more cogent illustration of the gained results is provided in Figure 1 below. As the data depicted in Table 2 demonstrate, a significant difference is encountered $(t=-4.97, \mathrm{df}=29, \mathrm{p}=.00 ; \leq .05)$ with regard to the performance of experimental group on pretest and posttest. Yet, this finding alone is not sufficient for the rejection of the null hypothesis of the study at hand and further analysis is called for.

Table 1. Descriptive Statistics for Group A Performance on Pretest and Posttest

\begin{tabular}{lllll}
\hline & Variable & N & Mean & $\begin{array}{c}\text { Std. } \\
\text { Deviation }\end{array}$ \\
\hline A & Pre - Test & 30 & 14.55 & 1.82 \\
& Post - Test & 30 & 15.58 & 1.39 \\
\hline
\end{tabular}

Table 2. Paired T-test Results for the Performance of Group A on Pretest and Posttest

\begin{tabular}{lcccccccc}
\hline & $\mathrm{N}$ & Mean & $\begin{array}{c}\text { Std. } \\
\text { Deviation }\end{array}$ & Correlation & Sig. & \multicolumn{2}{c}{ Paired Test } \\
& & & & $\mathrm{t}$ & $\mathrm{df}$ & Sig. \\
\hline $\begin{array}{l}\text { Pre - Test A } \\
\text { Post - Test A }\end{array}$ & 30 & -1.03 & 1.14 & 0.78 & .00 & -4.97 & 29 & .00 \\
\hline
\end{tabular}

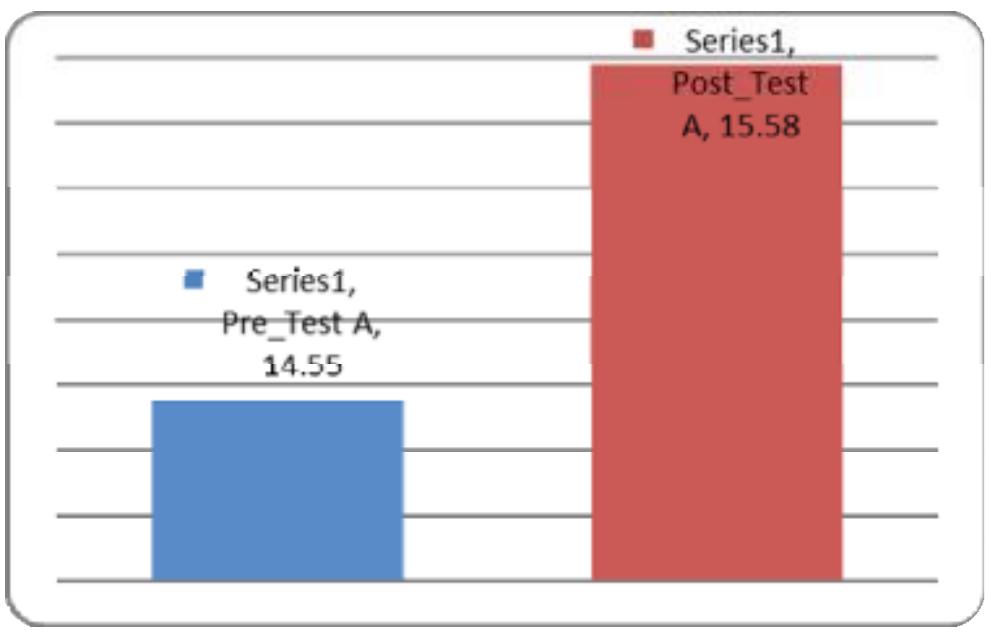

Figure 1. The Comparison of Mean Scores of Group A on both Pretest and Posttest 
International Journal of Applied Linguistics \& English Literature

ISSN 2200-3592 (Print), ISSN 2200-3452 (Online)

Vol. 1 No. 6; November 2012

\subsection{The Performance of Control Group on Pretest and Posttest}

Taking a brief glance at the results gained for group B (control group), one can conclude that unlike the experimental group, this group hasn't made a significant progress from pretest to posttest $(\mathrm{t}=.92, \mathrm{df}=29, \mathrm{p}=$ $.37 ;>.05)$ and hence another piece of evidence (though not definite yet) is gained for the usefulness of the treatment applied in the experimental (but not in the control) group. The data relevant to the performance of group B on pretest and posttest are briefed in Tables 3 and 4, and in Figure 2.

Table 3. Descriptive Statistics for Group B Performance on Pretest and Posttest

\begin{tabular}{lllll}
\hline & Variable & N & Mean & Std. Deviation \\
& & & & \\
& & & & \\
\hline B & Pre - Test & 30 & 12.73 & 1.97 \\
& Post - Test & 30 & 12.40 & 2.19 \\
\hline
\end{tabular}

Table 4. Paired T-test Results for the Performance of Group B on Pretest and Posttest

\begin{tabular}{lcccccc}
\hline & $\mathrm{N}$ & Mean & $\begin{array}{c}\text { Std. } \\
\text { Deviation }\end{array}$ & $\mathrm{t}$ & $\mathrm{d}$ & Paired Test \\
& & & 1.98 & .92 & 29 & .37 \\
\hline $\begin{array}{l}\text { Pre - Test B } \\
\text { Post - Test B }\end{array}$ & 30 & .33 & & & & \\
\hline
\end{tabular}

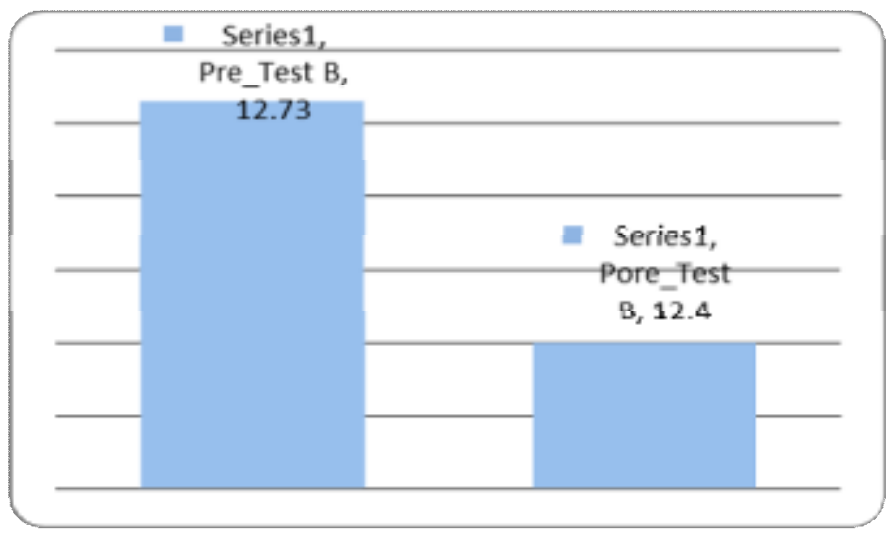

Figure 2. The Comparison of Mean Scores of Group B on both Pretest and Posttest

\subsection{Comparison of Experimental and Control Groups Posttest Results}

In line with the data presented in Table 5 below, a significant amount of difference is witnessed between the performances of both groups on the posttest $(\mathrm{t}=6.71, \mathrm{df}=49.04, p=.00 ; \leq .05)$.

Table 5. Independent Samples T-test Run for the Performance of both Groups on the Posttest

\begin{tabular}{|c|c|c|c|c|c|c|c|c|c|}
\hline & \multirow[t]{2}{*}{ variable } & \multirow[t]{2}{*}{$\mathrm{N}$} & \multirow[t]{2}{*}{ Mean } & \multirow[t]{2}{*}{$\begin{array}{l}\text { Std. } \\
\text { Deviation }\end{array}$} & \multicolumn{2}{|c|}{$\begin{array}{c}\text { Levene's Test for } \\
\text { Equality of Variances }\end{array}$} & \multicolumn{3}{|c|}{$\begin{array}{c}\text { t-test for Equality of } \\
\text { Means }\end{array}$} \\
\hline & & & & & $\mathrm{F}$ & Sig. & $\mathrm{t}$ & $\mathrm{df}$ & Sig. \\
\hline \multirow[t]{2}{*}{ Post - Test } & $\mathrm{A}$ & 30 & 15.58 & 1.39 & 8.78 & .000 & 6.71 & 49.04 & .000 \\
\hline & B & 30 & 12.40 & 2.19 & & & & & \\
\hline
\end{tabular}




\section{Discussion}

In this section, first a pithy summary of the findings obtained is presented and then the discussion over the gained findings is submitted in the light of the available similar body of work in the literature. The main mission of this study was to investigate the possible effect of task-complexity-based instruction of incidental vocabulary on the learners' vocabulary learning.

Based on the results gained, in brief, it was found that, compared to control group, experimental group made significant improvement in terms of vocabulary performance from pretest to posttest. Therefore, it can be concluded that the treatment applied in the experimental group which was based on task complexity, has proven more useful than the one utilized in the control group, in which the degree of task complexity for teaching incidental vocabulary was not kept within control. As no studies with the analogous framework were found within the literature, the pieces of research on which the researchers draw in the remainder of the discussion only partially overlap with the study at hand; yet, due to their highly similar natures to the current study, these studies are thought to greatly help substantiate the findings of the present study.

The results are very much akin to the ones obtained in a study by Javanbakht (2011). Working with 88 elementary Iranian EFL learners, he was aimed at gauging the impact of different task types on learners' incidental vocabulary learning. On account of the obtained results, he claimed that incidental vocabulary learning had significantly enhanced as a result of the application of tasks with varying degrees of involvement. Though there are slight differences between the study by Javanbakht (ibid.) and the current study (as he used only male participants and did not resort to task complexity as the main variable of the study), the overlapping upshots can be taken as supportive evidence for the general influence of task-based instruction on the process of (incidental) vocabulary learning.

Another study of the type was performed by Lertola (2012), in which the researcher was after measuring the effect of exposure to authentic material and focusing on the subtitling task on learners' retention of incidental vocabulary. A total of sixteen second-year university learners had participated in this project and, in line with the findings, the learners in both subtitling and non-subtitling groups had made considerable progress in terms of incidental vocabulary acquisition from pretest to immediate and delayed posttest. Though the procedure through which the study by Lertola has been implemented only partially overlaps with the current study, its results can provide some degree of support for the present study, in that both focus on the effects of some sort of involvement with tasks on the learners' improved vocabulary learning.

Finally, in an investigation which is in part similar to the current study, Neyadi (2007) performed an action research regarding the effects of using game tasks on the learners' retention of vocabulary. She then concluded that "using games to practice vocabulary improves learners' ability to memorize the words effectively. Games provide comprehensible input while learners interact in the group, allowing students to clarify meanings of words in such contexts" (p. 105).

\section{Concluding Remarks}

Task sequencing in terms of complexity and difficulty has always been regarded as a main determining factor contributing to the comprehensibility of the input provided for learners. Though a great deal has been done with regard to the implications of controlling task complexity and difficulty for the learners' improvement with the whole process of learning, the current study might be regarded as a unique study in its own right as it sheds light on some unattended aspects of task-based instruction, which mainly emanate from its noticeable orientation toward the effect of task-complexity-based instruction of incidental vocabulary on learners' general vocabulary learning process.

This study is thought to be laden with manifold implications for varied stakeholders within the realm of didactics, including language teachers, learners, syllabus designers, test developers, educational bodies and many other individuals in the ministries of education and higher education. The main significance of the obtained results lies in the fact that vocabulary instruction plays a key role in any instructional arena and hence coming up with appropriate ways for improving this fundamental component of language in learners can help alleviate much of the learners' problem with the whole process of learning. Furthermore, teachers can gain a lot from the experience of incidental vocabulary teaching for the overall betterment of the vocabulary knowledge in their learners.

The main implication of the current research for the syllabus designers can be drawing their attention toward the salience of designing instructional materials in neatly-sequenced order, say in terms of complexity, which, in 
turn, brings about an ameliorated learning in the individuals. Test developers can also be sensitized toward the paramountcy of proper task sequencing, while designing the tests. Altogether, the findings of the present study might help with a better implementation of task-based instruction, guided by observing task complexity, particularly in the domain of incidental vocabulary instruction from the vantage point of both teachers and learners.

\section{References}

Ahmad, J. (2011). Intentional vs. incidental vocabulary learning. Interdisciplinary Journal of Contemporary Research in Business, 3 (5), 67-75.

Behbahani, S. M. K., Pourdana, N., Maleki, M., \& Javanbakht, Z. (2011). EFL task-induced involvement and incidental vocabulary learning: succeeded or surrounded? International Conference on Languages, Literature and Linguistics. IPEDR Proceedings, 26, 323-325.

Breen, M. P. (1987). Contemporary paradigms in syllabus design. Language Teaching, 20 (3), 157-174.http://dx.doi.org/10.1017/S026144480000450X

Büyükkarci, K. (2009). A critical analysis of task-based learning. Kastamonu Education Journal, 17 (1), 313-320.

Bygate, M. (1996). Effects of task repetition: Appraising the developing language of learners. In J. Willis \& D. Willis (eds). Challenge and change in language teaching. (pp. 136-46). London: Heinemann.

Bygate, M. (2001). Effects of task repetition on the structure and control of oral language. In M. Bygate, P. Skehan, \& M. Swain (eds). Task-based learning: language teaching, learning and assessment. (pp.23-48). London: Longman.

Cobb, T. (1997). Is there any measurable learning from hands-on concordancing? System, 25, 301-15. http://dx.doi.org/10.1016/S0346-251X(97)00024-9

Cobb, T. \& Horst, M. (2001). Reading academic English: carrying learners across the lexical threshold. In J.

Flowerdew \& M. Peacock (eds), The English for academic purposes curriculum. (pp. 315-29). Cambridge:

Cambridge University Press.

Crookes, G. (1986). Task classification: A cross-disciplinary review (Tech. Rep. No. 4). Honolulu: University of Hawaii at Manoa, Social Science Research Institute, Center for Second Language Classroom Research.

Ellis, R. (2003). Task-based language learning and teaching. Oxford: OUP.

Ellis, R. (2009). The differential effects of three types of task planning on the fluency, complexity, and accuracy in L2 oral production. Applied Linguistics, 30 (4), 474-509. http://dx.doi.org/10.1093/applin/amp042

Eysenck, M.W. (1982). Incidental learning and orienting tasks. In C. Puff. (ed.). Handbook of research methods in human memory and cognition, (pp. 197-228). London: Academic Press.

Ghabanchi, Z., \& Ayoubi, E. S. (2012). Incidental vocabulary learning and recall by intermediate foreign language students: The influence of marginal glosses, dictionary use, and summary writing. Journal of International Education Research, 8 (2), 85-96.

Grace, C. (1999). Personality type, tolerance of ambiguity, and vocabulary retention in CALL. CALICO Journal, $15,19-45$.

Guara'-Tavares, M. G. (2008). Pre-task planning, working memory capacity and L2 speech performance. Unpublished Doctoral Thesis, Universidade Federal de Santa Catarina, Brazil.

Haastrup, K. (1991). Lexical inferencing procedures or talking about words. Tübingen: Narr.

Holley, F, M. (1973). A study of vocabulary learning in context: the effect of new-word density in German reading materials. Foreign Language Annals, 6, 339-47. http://dx.doi.org/10.1111/j.1944-9720.1973.tb02613.x Hulstijn, J. H. (1992). Retention of inferred and given word meanings: experiments in incidental vocabulary learning. In P. J. Arnaud \& H. Bejoint (eds), Vocabulary and applied linguistics. (pp. 113-25). London: Macmillan.

Hulstijn, J. H. (1993). When do foreign language readers look up the meaning of unfamiliar words? The influence of task and learner variables. Modern Language Journal, 77,

139-147.http://dx.doi.org/10.1111/j.1540-4781.1993.tb01957.x

Hulstijn, J.H. (2001). International and incidental second language vocabulary learning: A reappraisal of elaboration, rehearsal and automaticity. In P. Robinson (Ed.), Cognition and second language instruction. (pp. 258-286). Cambridge: Cambridge University Press. 
International Journal of Applied Linguistics \& English Literature

ISSN 2200-3592 (Print), ISSN 2200-3452 (Online)

Vol. 1 No. 6; November 2012

Hulstijn, J. H., Hollander, M. \& Greidanus, T. (1996). Incidental vocabulary learning by advanced foreign language students: The influence of marginal glosses, dictionary use and reoccurrence of unknown words. Modern Language Journal, 80, 327-339. http://dx.doi.org/10.1111/j.1540-4781.1996.tb01614.x

Javanbakht, Z. O. (2011). The impact of tasks on male Iranian elementary EFL learners' incidental vocabulary learning. Language Education in Asia, 2 (1), 28-42.

Jing, L., \& Jianbin, H. (2009). An empirical study of the involvement load hypothesis in incidental vocabulary acquisition in EFL listening. Polyglossia, 16, 1-11.

Knight, S. (1994). Dictionary use while reading: The effect on comprehension and vocabulary acquisition for students of different verbal abilities. Modern Language Journal, 78,

285-299.http://dx.doi.org/10.1111/j.1540-4781.1994.tb02043.x

Krantz, G. (1990). Learning vocabulary in a foreign language: A study of reading strategies. Göteborg: Acta Universitatis Gothoborgensis.

Lertola, J. (2012). The effect of the subtitling task on vocabulary learning, In A. Pym \& D. Orrego-Carmona (Eds.) Translation Research Project 4, Tarragona: Intercultural Studies Group, Universitat Rovira i Virgili, 61-70.

Lijuan, Q. (2010). An empirical study of meaning negotiation from the perspective of task characteristics - task difficulty and task complexity. Chinese Journal of Applied Linguistics, 33 (4), 45-63.

Long, M. H. (1985). A role for instruction in second language acquisition. Task-based language teaching. In K. Hyltenstam \& M. Pienemann (eds). Modelling and assessing second language acquisition. (pp. 77-99).

Clevedon, England: Multilingual Matters.

Long, M. H., \& Crookes, G. (1992). Three approaches to task-based syllabus design. TESOL Quarterly, 26 (1), 27-56. http://dx.doi.org/10.2307/3587368

Mahdavy, B. (2011). The role of topic familiarity and rhetorical organization of texts in L2 incidental vocabulary acquisition. Procedia - Social and Behavioral Sciences, 29, 208-217.

McCarthy, M. \& O'Dell, F. (2010). English vocabulary in use (elementary). Cambridge: CUP.

Nation, I.S.P. (2001). Learning vocabulary in another language. Cambridge: C.U.P.

Neyadi, O. S. (2007). The effects of using games to reinforce vocabulary learning. In K. Gallagher \& K.

Bashir-Ali (eds.). Action research and initial teacher education in the UAE (pp. 99-107). UAE: HCT Press.

Parreren, C.F. van \& Schouten-van Parreren, M.C. (1981). Contextual guessing: a trainable reader strategy.

System, 9 (3), 235-241. http://dx.doi.org/10.1016/0346-251X(81)90046-4

Prabhu, N. (1987). Second language pedagogy: a perspective. Oxford: Oxford University Press.

Rahimpour, M. (2007). Task complexity and variation in L2 learners' oral discourse. The University of

Queensland Working Papers in Linguistics, 1, 1-9.

Richards, J., \& Rodgers, T. (2001). Approaches and methods in language teaching. Cambridge: Cambridge University Press. http://dx.doi.org/10.1017/CBO9780511667305

Robinson, P. (2001). Task complexity, task difficulty, and task production: Exploring interactions in a componential framework. Applied Linguistics, 1, 27-57. http://dx.doi.org/10.1093/applin/22.1.27

Roby, Warren B. (1999). What's in a gloss? Language Learning \& Technology, 2 (2), 94-101.

Rott, S. (1999). The effect of exposure frequency on intermediate language learners' incidental vocabulary acquisition and retention through reading. Studies in second language acquisition, 21,

589-619.http://dx.doi.org/10.1017/S0272263199004039

Ruso, N. (2007). The influence of task based learning on EFL classrooms. Asian EFL Journal, 18. Retrieved from http://www.asian-efl-journal.com/pta_February_2007_nr.php

Sánchez, A. (2004). The task-based approach in language teaching. International Journal of English Studies, 4 (1), 39-71.

Sangarun, J. (2005). The effects of focusing on meaning and form in strategic planning. In R. Ellis (ed.).

Planning and task performance in a second language. John Benjamins.

Swanborn, M. S. L. \& de Glopper K. (2002). Impact of reading purpose on incidental word learning from context. Language Learning, 52, 95- 117. http://dx.doi.org/10.1111/1467-9922.00178

Wu, L. (2009). Incidental English vocabulary studying in L2 learning. Unpublished MA Thesis. Kristianstad University College: The School of Teacher Education.

Yuan, F., \& Ellis, R. (2003). The effects of pre-task and on-line planning on fluency, complexity and accuracy in L2 monologic oral production. Applied Linguistics, 24 (1), 1-27. http://dx.doi.org/10.1093/applin/24.1.1 